\title{
Anna Wiśniewska*
}

\section{OBSZARY WYKORZYSTANIA WALUT WIRTUALNYCH W DZIAŁALNOŚCI PRZEDSIĘBIORSTWA}

Z a r y s t r e ś c i: Dynamiczny rozwój rynku walut wirtualnych stawia przed przedsiębiorcami wiele wyzwań, ale również i możliwości. Niniejszy artykuł ma na celu zaprezentowanie wybranych obszarów wykorzystania walut wirtualnych przez przedsiębiorstwa wraz ze wskazaniem potencjalnych korzyści i zagrożeń związanych z kryptowalutami. W pracy wykorzystano analizę literatury, a także dostępnych źródeł internetowych. Po krótkiej charakterystyce walut wirtualnych, przedstawiono możliwości ich wykorzystania w promocji przedsiębiorstw, w pozyskiwaniu kapitału oraz jako sposobu płatności.

S ł o w a k l u c z o w e: kryptowaluty, waluty wirtualne, promocja przedsiębiorstw, finansowanie przedsiębiorstw

K 1 a s y fi k a c j J E L: E42; G21; G32

\section{WSTĘP}

Gdy w roku 2008 osoba (bądź grupa osób) pod pseudonimem Satoshi Nakamoto opublikowała artykuł pod tytułem „Bitcoin: A Peer to Peer Electronic Cash System”, idea stworzenia „oficjalnego pieniądza Internetu” nie była niczym nowym. Wcześniej do realizacji takiego pomysłu przystąpili m.in. D. Chaum (DigiCash) oraz D. Jackson i B. K. Downey (E-cash). Ich starania nie odniosły jednak sukcesu, po części z powodu niedostatecznego popytu, ale również niekorzystnych przepisów prawnych [Wiśniewska, 2015, s. 5-6]. Mimo istniejących kontrowersji, system Bitcoin oraz jego jednostka - bitcoin, spotkały się z dużym zainteresowaniem osób indywidualnych, przedsiębiorców i organizacji międzynarodowych oraz państwowych. Oczywiście powody

1 Adres do korespondencji: Anna Wisniewska, Uniwersytet Mikołaja Kopernika w Toruniu, Wydział Nauk Ekonomicznych i Zarządzania, Katedra Ekonomii, ul. Gagarina 13a, 87-100 Toruń, e-mail: amw@doktorant.umk.pl 
zainteresowania bitcoinem wyżej wymienionych podmiotów są różne. Wynika to $\mathrm{z}$ mnogości możliwych zastosowań, nie zawsze zgodnych z prawem, oraz z motywu spekulacyjnego.

Pewne cechy bitcoina i powstałych na fali jego popularności alternatywnych kryptowalut, tzw. altcoins, czynią je bardziej atrakcyjnymi niż tradycyjny pieniądz i tradycyjne systemy płatnicze. Ponadto gwałtowne wahania cen walut wirtualnych zachęcają do spekulacji. Potencjał tkwiący w kryptowalutach został dostrzeżony również przez przedsiębiorców. Celem tego artykułu jest wskazanie niektórych obszarów wykorzystania walut wirtualnych w przedsiębiorstwie oraz ich krótka charakterystyka wraz z oceną potencjalnych zagrożeń i korzyści. Ze względu na liczbę istniejących walut wirtualnych, których według CoinMarketCap.com w lutym 2018 roku było ponad 1500 [CoinMarketCap.com, 2018], w pracy skupiono się głównie na najpopularniejszej z nich - bitcoinie.

\section{WALUTY WIRTUALNE - PROBLEM DEFINICJI}

Kryptowaluty stanowią stosunkowo nowe zjawisko, które gwałtownie się rozwija, co związane jest przede wszystkim z łatwością tworzenia nowych walut wirtualnych. W tabeli 1 przedstawiono zestawienie 10 najpopularniejszych pod względem udziału w całkowitym wolumenie transakcji w dniu 25 lutego 2018 roku walut wirtualnych. Na podstawie informacji w niej zawartych można wysnuć wniosek, że zaledwie kilka z istniejących kryptowalut cieszy się dużym zainteresowaniem użytkowników, pozostałe mają znikomy udział w rynku, co uzasadnia ograniczenie rozważań do bitcoina.

Tabela 1. Zestawienie kryptowalut pod względem udziału w całkowitym wolumenie transakcji w dniu 25 lutego 2018 r.

\begin{tabular}{|l|l|lr|}
\hline I.p. & Nazwa & $\begin{array}{l}\text { Udział w całkowitym wolumenie } \\
\text { w procentach }\end{array}$ & transakcji \\
\hline 1. & Bitcoin & & $38,35 \%$ \\
\hline 2. & Tether & & $13,10 \%$ \\
\hline 3. & Ethereum & & $10,85 \%$ \\
\hline 4. & Litecoin & & $5,60 \%$ \\
\hline 5. & Ethereum Classic & & $4,91 \%$ \\
\hline 6. & Bitcoin Cash & $2,39 \%$ \\
\hline 7. & Ripple & & $2,19 \%$ \\
\hline 8. & Nano & & $1,52 \%$ \\
\hline 9. & TRON & & $1,17 \%$ \\
\hline 10. & EOS & $1,02 \%$ \\
\hline
\end{tabular}

Źródło: https://coinmarketcap.com/ [25.02.2018 r.]. 
Początkowa popularność kryptowalut związana była m.in. ze spadkiem zaufania do systemu bankowego po kryzysie subprime, w czym też upatruje się przyczyn ich powstania [Chrabonszczewska, 2014, s. 51]. Stąd też istniejące definicje często ograniczają się do opisu ich funkcjonowania. Europejski Bank Centralny (EBC) oraz The Financial Action Task Force (FATF) podjęły próbę klasyfikacji kryptowalut w oparciu o kierunek przepływu środków. EBC sugeruje, że waluta wirtualna to odpowiedź społeczności wirtualnej na potrzebę posiadania własnego pieniądza (waluty), który pełniłby te same funkcje, co pieniądz tradycyjny i ułatwiał wymianę dóbr i usług [European Central Bank, 2012, s. 5]. FATF natomiast definiuje walutę wirtualną jako „cyfrową reprezentację wartości, którą można cyfrowo handlować i która funkcjonuje jako środek wymiany i/lub jednostka rozrachunkowa i/lub środek tezauryzacji, lecz nie ma statusu prawnego środka płatniczego w żadnej jurysdykcji." [FATF, 2014, s. 4]. Obie instytucje w swoich raportach skupiają się głównie na funkcjach pieniądza, które waluty wirtualne mogą pełnić, wskazując, że właśnie rola środka płatniczego była wówczas uznawana za przyszły kierunek rozwoju kryptowalut. Według klasyfikacji FATF, waluty wirtualne wraz z pieniądzem elektronicznym określa się wspólnym mianem walut cyfrowych [FATF, 2014, s. 4]. Należy jednak zwrócić uwagę na fakt, że niektórzy badacze skłaniają się do zastąpienia terminu „waluta wirtualna” właśnie określeniem ,waluta cyfrowa” thumacząc to negatywnymi skojarzeniami, gdyż słowo „wirtualna” kojarzy się z czymś, co nie istnieje w realnym świecie [Lee, 2015, s. 6].

Biorąc pod uwagę kierunek przepływu środków, klasyfikacje FATF oraz EBC są do siebie bardzo podobne, jednakże ta przedstawiona przez EBC jest bardziej szczegółowa. Wyróżnia ona bowiem waluty wirtualne [European Central Bank, 2012, s. 13-14]:

- zamknięte,

- o jednokierunkowym przepływie środków,

- o dwukierunkowym przepływie środków.

Waluty wirtualne zamknięte nie mają związku z rzeczywistą gospodarką. Powstają i są wydawane jedynie w ramach pewnej zamkniętej społeczności, np. w komputerowej grze. Pewne aktywności w ramach społeczności są nagradzane jednostką takiej waluty, a uzbierane jednostki można wydać jedynie na zakup dóbr i usług oferowanych w ramach gry. Nie można jednak nabyć jednostek takiej waluty wirtualnej za tradycyjny pieniądz. Taką możliwość dają waluty wirtualne o jednokierunkowym przepływie środków (rzadziej spotyka się możliwość wyłącznie wymiany waluty wirtualnej na pieniądz tradycyjny). Tu przykładem mogą być programy lojalnościowe oferowane przez sklepy. Ostatni z rodzajów walut wirtualnych umożliwia zarówno zakup jak i sprzedaż jednostki waluty za pieniądz fiducjarny. FATF określa ten typ waluty wirtualnej mianem 
otwartej. Jeśli ponadto otwarta waluta wirtualna wykorzystuje zaawansowane narzędzia kryptograficzne i jest zdecentralizowana - można ją nazwać kryptowalutą [FATF, 2014, s. 5].

Pojawiają się opinie, że definicje przedstawione przez Europejski Bank Centralny oraz The Financial Action Task Force są niepełne. Biorąc pod uwagę, że od 2017 roku obserwuje się gwałtowny wzrost zainteresowania rynkiem kryptowalut o charakterze spekulacyjnym, można stwierdzić, że istnieje potrzeba zrewidowania dotychczasowych definicji, gdyż pierwotny kierunek rozwoju walut wirtualnych odbiegł znacząco od zakładanego przez te instytucje. Stąd też niektórzy badacze skupiają się w swoich definicjach na cechach kryptowalut, bardziej niż na możliwości pełnienia przez nie funkcjo pieniądza, podkreślając:

- ich cyfrową formę oraz brak nadzoru ze strony władz państwowych [Bala, Kopyściański, Srokosz, 2016, s. 52-53],

- brak zabezpieczenia jakimkolwiek aktywem [Franco, 2015, s. 3] (co jednak nie zawsze musi być spełnione, jak pokazuje przykład kryptowaluty SmartCoin [BitShares, b.d.]),

- posiadanie przez nie wartości spowodowane wyłącznie uzgodnieniem ich użytkowników, że mają wartość [Ali, Barrdear, Clews, Southgate, 2014, s. 278],

- że tworzone są przez osoby indywidualne lub przedsiębiorstwa, a nie przez banki centralne [White, 2015, s. 383].

Inni natomiast pozostają przy przekonaniu, że waluty wirtualne są pieniądzem, który istnieje w internecie [Pacy, 2014, s. 122; Sauer, 2016, s. 118], a nawet, że są formą pieniądza elektronicznego [Ryfa, 2014, s. 141]. Mimo, że niektóre waluty wirtualne operują jako środek wymiany, nie są jeszcze pieniądzem w rozumieniu nauk ekonomicznych. Należy mieć jednak na uwadze, że nie oznacza to, iż w przyszłości nim się nie staną [Davidson, Block, 2015, s. 312].

\section{KRYPTOWALUTY JAKO SPOSÓB PŁATNOŚCI}

System Bitcoin, w zamierzeniu twórcy (twórców), miał stanowić skuteczną alternatywę dla tradycyjnych sposobów transferu środków pieniężnych. Miał być tańszy, szybszy, bardziej anonimowy i efektywny [Nakamoto, 2008, s. 1]. Jest więc zupełnie zrozumiałe, że znalazł on zastosowanie jako forma rozliczeń finansowych. W obliczu wzrostu znaczenia płatności bezgotówkowych, co przedstawia chociażby rosnąca liczbą terminali POS w krajach Unii Europejskiej [NBP, 2017, s. 14], można uznać, że wpisuje się to również w panujący trend odejścia od pieniądza gotówkowego.

$\mathrm{Na}$ całym świecie stacjonarnych miejsc akceptujących bitcoiny jako formę płatności było w lutym 2018 roku niemal dwanaście tysięcy [Coinmap.org, 2018]. Na wykresie 1 przedstawiono jak zmieniała się liczba takich miejsc od 
lutego 2013 roku do lutego 2018 roku. Można zauważyć, że zainteresowanie przedsiębiorców przyjmowaniem płatności w bitcoinach wzrasta.

Wykres 1. Liczba stacjonarnych miejsc akceptujących bitcoiny jako formę płatności w okresie od lutego 2013 r. do lutego 2018 r.

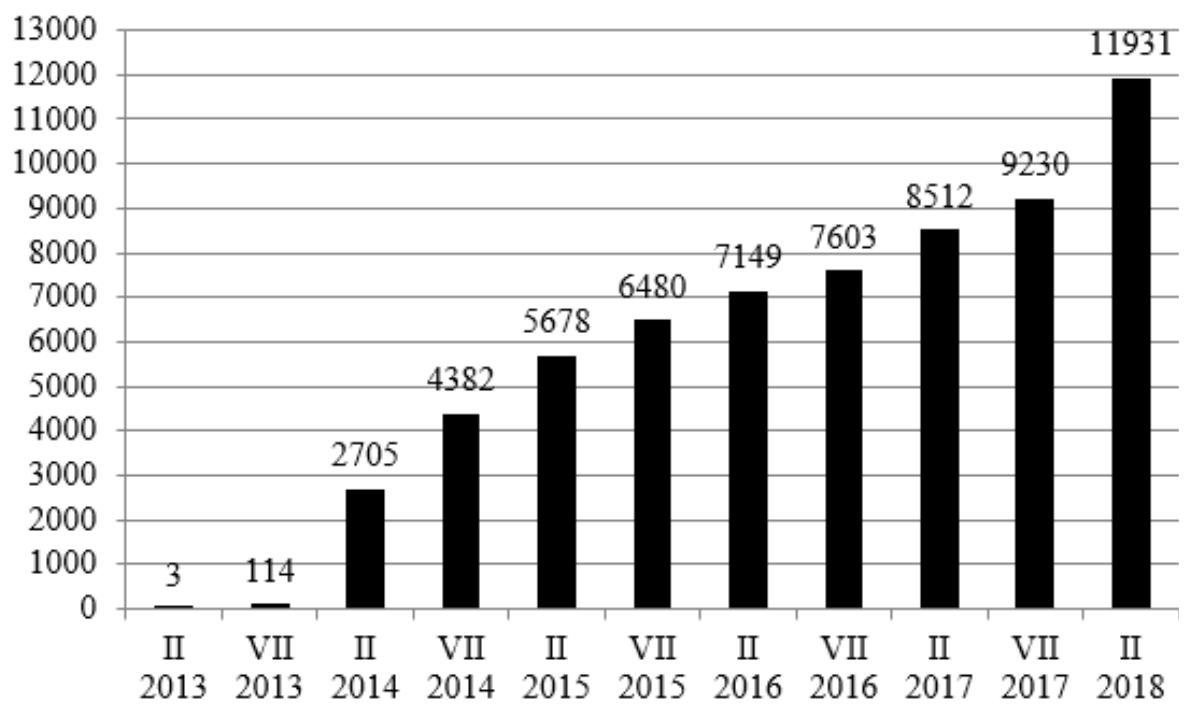

Źródło: www.coinmap.org [27.02.2018 r.].

Przedsiębiorcy decydujący się na akceptowanie płatności bitcoinami lub innymi walutami wirtualnymi mogą samodzielnie stworzyć system płatności od podstaw, bądź też z skorzystać z operatorów płatności. Operatorzy płatności bitcoin, jak np. BitBay Pay, kierują swoją ofertę zarówno do stacjonarnych, jak i internetowych punktów usługowych oraz sklepów. Przedsiębiorca może otrzymać wpłatę w kryptowalucie albo wybrać pieniądz tradycyjny. Ten drugi przypadek jest korzystniejszy ze względu na duże wahania kursowe kryptowalut, a także aspekty fiskalne [BitBay Pay, 2018]. W Polsce do celów opodatkowania VAT, bitcoin jest traktowany jako środek płatniczy, natomiast w przypadku podatku dochodowego od osób fizycznych, jako prawo majątkowe [Nowak, 2016, s. 2]. Główną zaletą przyjmowania płatności w bitcoinie jest szybkość transakcji i jej niskie koszty, zwłaszcza w przypadku płatności zagranicznych

Z punktu widzenia konsumenta płatność bitcoinami nie cechuje się dużym stopniem trudności. W przypadku posiadania portfela mobilnego transakcja sprowadza się do zeskanowania kodu QR, który udostępnia sprzedawca, bądź też podania adresu portfela w przypadku płatności internetowych [Bitcoin. pl, b.d.]. Warto jednak zwrócić uwagę na fakt, że dokonanie zapłaty za dobra 
i usługi przy użyciu innych rodzajów portfela może być znacznie trudniejsze. Przykładem mogą być portfele sprzętowe lub fizyczne, a w skrajnym przypadku tzw. brain wallet, czyli zapamiętanie klucza publicznego [Piech, 2017, s. 39].

Potencjał tkwiący w akceptowaniu płatności bitcoinami dostrzegło wiele znanych przedsiębiorstw w Polsce i na świecie. Za pomocą kryptowalut, można dokonać zakupu dóbr i usług oferowanych przez m.in.:

- portal Pyszne.pl [Tomaszewski, 2017],

- Microsoft,

- Wikipedię,

- WordPress.com [CryptoNews.pl, 2017].

\section{KRYPTOWALUTY W PROMOCJI PRZEDSIĘBIORSTW}

Dotychczas niemal pomijanym w literaturze przedmiotu obszarem zastosowań kryptowalut w przedsiębiorstwie jest jego szeroko pojęta promocja. Tymczasem akceptowanie kryptowalut jako formy płatności pozwala m.in. przyciągnąć określoną grupę klientów [Siekierska, 2017]. Badanie ankietowe przeprowadzone w 2013 roku wśród 533 użytkowników bitcoina, wskazało, że przeciętny respondent jest 32-letnim mężczyzną, przy czym największą grupę stanowią osoby w przedziale wiekowym 25-29 lat. Respondenci za pomocą tej kryptowaluty nabywali dobra i usługi związane głównie z branżą IT, natomiast zainteresowanie kryptowalutami spowodowane było przede wszystkim ciekawością, możliwością zarobku i sytuacją polityczną [Durden, 2013]. Warto jednak zwrócić uwagę, że badania te nie zostały przeprowadzone w sposób profesjonalny, można je więc jedynie traktować jako próbę scharakteryzowania użytkowników bitcoina. Mimo to, dają one pewien ogląd na to, kim w 2013 roku byli użytkownicy bitcoina i do jakich klientów przedsiębiorstwo może dotrzeć, gdy zdecyduje się na akceptowanie płatności w tej kryptowalucie. Jest zasadne stwierdzenie, że będą to przede wszystkim osoby młode, które interesują się nowinkami technologicznymi.

Przedsiębiorstwa akceptujące bitcoiny jako formę płatności mogą również umieścić taką informację na forach i portalach poświęconych kryptowalutom. Wiele stron internetowych o tej tematyce, np. Fintek.pl, Coinmap.org, czy też Bitcoin.pl, publikuje informacje o akceptantach płatności w walutach wirtualnych. Jak wykazały badania przeprowadzone wśród organizacji funkcjonujących w darknecie, przyjmowanie płatności w kryptowalutach, zwłaszcza alternatywnych, stanowi dla nich szansę na wyróżnienie się spośród pozostałych istniejących na rynku i zdobycie tym samym przewagi konkurencyjnej [Afilipoaie, Shortis, 2015, s. 3]. 


\section{KRYPTOWALUTY JAKO FORMA POZYSKIWANIA KAPITAŁU}

Wspomniane wcześniej obszary zastosowań walut wirtualnych w przedsiębiorstwie skupiały się przede wszystkim na oferowaniu klientom możliwości dokonywania płatności przy pomocy kryptowalut. Niektóre organizacje dostrzegły w walutach wirtualnych również szansę na pozyskiwanie kapitału, również na rozpoczęcie swojej działalności.

Można wyróżnić kilka sposobów wykorzystania kryptowalut jako formy pozyskiwania kapitału. Pierwszy z nich to inwestycje. Przedsiębiorstwo angażuje swoje środki finansowe w spekulację na cenach kryptowalut, pozyskując kapitał poprzez sprzedaż kryptowaluty. Drugi sposób związany jest ze stworzeniem własnej kryptowaluty, jej wypromowaniem oraz sprzedażą. Warto tutaj wspomnieć o konieczności odróżnienia tych przedsiębiorstw, których celem jest stworzenie własnej kryptowaluty od tych, które jej emisję traktują jedynie jako alternatywne źródło finansowania swojej działalności. Przykładem przypadku pierwszego jest przedsiębiorstwo CashBet Coin, które zawarło współpracę z FC Arsenal w celu wypromowania swojej waluty wirtualnej, która w zamierzeniu ma być wykorzystywana m.in. w zakładach internetowych [Comparic.pl, 2018].

Pierwsza emisja stworzonej przez przedsiębiorstwo kryptowaluty nosi nazwę Initial Coin Offering (ICO). Uproszczona procedura pozyskiwania finansowania poprzez kryptowalutę przedstawia się następująco [Bazan, 2018]:

- stworzenie kryptowaluty,

- wprowadzenie kryptowaluty na wybraną giełdę walut wirtualnych,

- promocja kryptowaluty,

- sprzedaż kryptowaluty i otrzymanie w ten sposób pieniądza tradycyjnego lub bardziej popularnych kryptowalut.

Na każdym z wymienionych etapów, poza wprowadzeniem na giełdę, przedsiębiorstwo może skorzystać z gotowych rozwiązań, np. platform umożliwiających stworzenie własnej kryptowaluty, bądź próbować wypracować je samodzielnie. Taka forma pozyskiwania kapitału stanowi nowe zjawisko, stąd też decyzja o jej zastosowaniu powinna być szczególnym stopniu przemyślana i poprzedzona odpowiednimi analizami.

\section{KORZYŚCI I ZAGROŻENIA ZWIĄZANE Z WYKORZYSTYWANIEM KRYPTOWALUT PRZEZ PRZEDSIĘBIORSTWO}

Każdy z opisanych wyżej obszarów wykorzystania kryptowalut przez przedsiębiorstwo wiąże się z zagrożeniami, ale może też przynieść pewne korzyści. Do najważniejszych zagrożeń wynikających ze stosowania walut wirtualnych 
w działalności przedsiębiorstwa należą te związane $\mathrm{z}$ opodatkowaniem i przepisami prawa. Niewystarczające regulacje powodują, że przedsiębiorstwa mogą być zmuszone wystąpić o indywidualną interpretację podatkową. W działalności międzynarodowej konieczne jest również upewnienie się, czy kryptowaluty są legalne w danym państwie.

Kolejna grupa zagrożeń związana jest z wahaniami kursu kryptowalut, które mogą być bardzo gwałtowne oraz brakiem jakiegokolwiek zabezpieczenia ze strony państwa. W przypadku przyjmowania płatności w kryptowalucie, zasadne jest rozważenie skorzystania z możliwości natychmiastowego przewalutowania na pieniądz tradycyjny. Z kolei przedsiębiorca decydujący się na pozyskanie kapitału poprzez emisję kryptowaluty powinien mieć na uwadze możliwość niedostatecznego zainteresowania potencjalnych nabywców.

Wśród najistotniejszych zalet warte wspomnienia są korzyści wizerunkowe, związane z postrzeganiem przedsiębiorstwa jako nowoczesnego i korzystającego z nowych technologii, a także możliwość dotarcia do określonej grupy klientów. Z kolei pozyskiwanie funduszy na działalność przedsiębiorstwa poprzez emisję kryptowaluty może stanowić alternatywę dla tych, które mają problem ze skorzystaniem z tradycyjnych form, np. mają trudności z otrzymaniem kredytu. Ponadto środki finansowe pozyskane ze sprzedaży kryptowaluty mogą pochodzić z każdego miejsca na świecie [Bazan, 2018], co oznacza, że przedsiębiorstwo może dotrzeć do znacznie większej liczby osób chętnych do zainwestowania swojego kapitału.

\section{PODSUMOWANIE}

Wskazane powyżej obszary wykorzystania kryptowalut przez przedsiębiorstwo stanowią jedynie część istniejących możliwości. Biorąc pod uwagę fakt, że jeszcze do niedawna pozyskiwanie funduszy na działalność przedsiębiorstwa poprzez kryptowaluty nie występowało, a rynek i stojąca za nim technologia rozwija się bardzo dynamicznie, można uznać, że w przyszłości może pojawić się znacznie więcej obszarów ich zastosowań.

Niemal niezbadanym obszarem jest wpływ wykorzystywania kryptowalut przez przedsiębiorstwo na jego wizerunek, a także możliwości promocji przedsiębiorstwa za ich pomocą. Znacznie lepiej poznany jest aspekt akceptowania płatności w kryptowalutach i można wysnuć przypuszczenie, że obecnie jest to dominujący sposób wykorzystywania walut wirtualnych przez przedsiębiorstwa, których działalność nie jest związana z nimi bezpośrednio.

Zastosowanie kryptowalut w swojej działalności stawia przed przedsiębiorstwami wiele wyzwań. Stąd konieczne jest rozważenie możliwych zagrożeń oraz potencjalnych korzyści. Kryptowaluty są zjawiskiem nowym, dynamicznie się 
rozwijającym i wciąż nie do końca zbadanym oraz niewystarczająco uregulowanym prawnie, co stanowi dla legalnie działających przedsiębiorstw istotną wadę.

\section{LITERATURA}

Afilipoaie A., Shortis P., (2015), The Growing Industry of Darknet Marketing, https://www.swansea.ac.uk/media/GDPO\%20SA\%20Marketing.pdf [25.02.2018].

Ali R., Barrdear J., Clews R., Southgate J., (2014), The economics of digital currencies, „Bank of England Quarterly Bulletin", Q3.

Bala S., Kopyściański T., Srokosz W., (2016), Kryptowaluty jako elektroniczne instrumenty płatnicze bez emitenta. Aspekty informatyczne, ekonomiczne i prawne, Wydawnictwo Uniwersytetu Wrocławskiego, Wrocław.

Bazan W., (2018), Kryptowaluty - nowa możliwość zdobycia kapitału, http://www.rp.pl/Firma/ 301269991-Kryptowaluty---nowa-mozliwosc-zdobycia-kapitalu.html [15.02.2018].

BitBay Pay, (2018),. https://bitbaypay.com/\#bitbay-pay-features [25.02.2018].

Bitcoin.pl, (b.d.), Akceptuj bitcoiny z operatorem płatności BitBayPay.com, http://bitcoin.pl/ poradniki/ecommerce/1416-akceptuj-bitcoiny-z-operatorem-platnosci-bitbaypay-com [25.02.2018].

BitShares, (b.d.), https://bitshares.org/ [25.02.2018].

Chrabonszczewska E., (2014), Bitcoin - Nowa Wirtualna Globalna Waluta?, „International Journal of Management and Economics", 40(1), https://doi.org/10.2478/ijme-2014-0028.

Coinmap.org, (2018), https://coinmap.org/ [25.02.2018].

CoinMarketCap.com, (2018), Cryptocurrency Market Capitalizations, https://coinmarketcap.com/ [25.02.2018].

Comparic.pl, (2018), Klub piłkarski Arsenal FC wchodzi w rynek kryptowalut, https://comparic.pl/ klub-pilkarski-arsenal-fc-wchodzi-rynek-kryptowalut/ [15.02.2018].

CryptoNews.pl, (2017), Coraz więcej gigantów akceptuje Bitcoin. Czy Alibaba będzie następny?, https://cryptonews.pl/alibaba/ [15.02.2018].

Davidson L., Block W. E., (2015), Bitcoin, the Regression Theorem, and the Emergence of a New Medium of Exchange, „Quarterly Journal of Austrian Economics”, 18(3).

Durden T., (2013), The Demographics Of Bitcoin, https://www.zerohedge.com/news/2013-03-10/ demographics-bitcoin [27.02.2018].

European Central Bank, (2012), Virtual currency schemes, European Central Bank, Frankfurt-onMain.

FATF, (2014), Virtual Currencies. Key Definitions and Potential AML/CFT Risks, http://www. fatf-gafi.org/media/fatf/documents/reports/Virtual-currency-key-definitions-and-potential-aml-cft-risks.pdf [27.02.2018].

Franco P., (2015), Understanding bitcoin: cryptography, engineering and economics, Wiley, Chichester.

Lee D. (red.), (2015), Handbook of digital currency: bitcoin, innovation, financial instruments, and big data, Elsevier/AP, Amsterdam.

Nakamoto S., (2008), Bitcoin: A Peer-to-Peer Electronic Cash System, https://bitcoin.org/bitcoin. pdf [27.02.2018]

NBP, (2017), Porównanie wybranych elementów polskiego systemu płatniczego z systemami innych krajów Unii Europejskiej za 2016 r., NBP, Warszawa.

Nowak P., (2016), Odpowiedź na interpelację nr 6655 złożona przez Pana Posła Mirosława Suchonia $w$ sprawie Bitcoin, http://orka2.sejm.gov.pl/INT8.nsf/klucz/658C47ED/\%24FILE/ i06655-o1.pdf [27.02.2018]. 
Pacy E. P., (2014), Tales from the Cryptocurrency: On Bitcoin, Square Pegs, and Round Holes, „New England Law Review”, 49(1).

Piech K. (red.), (2017), Podstawy korzystania z walut cyfrowych, Instytut Wiedzy i Innowacji.https:// www.gov.pl/documents/31305/436699/Podstawy+walut+cyfrowych.pdf [27.02.2018].

Ryfa J., (2014), Waluty wirtualne - problem zdefiniowania i klasyfikacji nowego środka płatniczego, „Nauki o Finansach”, 2 (19).

Sauer B., (2016), Virtual Currencies, the Money Market, and Monetary Policy, „International Advances in Economic Research", 22(2), https://doi.org/10.1007/s11294-016-9576-x.

Siekierska M., (2017), 5 powodów, dla których warto korzystać z bitcoina, https://www.payu.pl/ blog/5-powodow-dla-ktorych-warto-korzystac-z-bitcoina [15.02.2018].

Tomaszewski R., (2017), Na Pyszne.pl można już płacić bitcoinami, https://fintek.pl/pyszne-pl-mozna-juz-placic-bitcoinami/ [27.02.2018].

White L. H., (2015), The market for cryptocurrencies, „Cato Journal”, 35.

\title{
VIRTUAL CURRENCIES IN AN ENTREPRENEURSHIP - AREA OF APPLICATION
}

\begin{abstract}
The dynamic development of the virtual currencies' market may pose new challenges and open up further possibilities for entrepreneurships. The aim of this paper is to present some applications of virtual currencies in companies as well as potential benefits and threats of cryptocurrencies. In the study there have been used the literature on the subject as well as available Internet sources. After a brief introduction to the idea of virtual currencies, there have been presented such areas of use as business promotion, payments and capital raising.
\end{abstract}

Keywords: cryptocurrencies, virtual currencies, business promotion, corporate finance. 